\title{
Prevention of bone metastases and management of bone health in early breast cancer
}

Michael Gnant ${ }^{* *}$ and Peyman Hadji2

\begin{abstract}
Treatment options for women with early-stage breast cancer have never been better, and the addition of bisphosphonates to adjuvant therapy is a valuable new tool capable of substantially improving clinical outcomes for these women. Several recent studies demonstrated that the anticancer activity of bisphosphonates is not limited to bone, and can translate into a reduction in disease recurrence, including reductions in locoregional and distant metastases. In addition, bisphosphonates maintain bone health during adjuvant therapy; this may be especially important for women who are at high risk for fracture.
\end{abstract}

\section{Introduction}

Women with early-stage breast cancer generally have a favorable prognosis after first-line treatment and surgical resection. Adding adjuvant therapy, especially for patients at high risk of recurrence, has been shown to improve outcomes, although such therapies may be associated with deteriorations in bone health [1]. When disease does recur in these patients, it is typically not at the primary tumor site but rather from cancer stem cells (CSCs) that metastasize to distant sites, such as the bone marrow [2]. In these sites, interactions between the CSCs and the normal tissue can create niches that facilitate cancer cell dormancy, allowing the CSCs to evade the cytotoxic or proapoptotic effects of therapies while maintaining their capacity to seed future metastases $[3,4]$.

Fortunately, the multistep process required for cancer metastasis (for example, cancer cell mobilization, invasion into the vasculature, extravasation at distant sites, and angiogenesis) affords many opportunities for

*Correspondence: michael.gnant@meduniwien.ac.at

'Department of Surgery, Medical University of Vienna, A-1090 Währinger Gürtel

18-20, Vienna, Austria

Full list of author information is available at the end of the article therapeutic intervention. Recent evidence has revealed that bisphosphonates, which have been investigated for protecting bone health in women receiving adjuvant therapy for breast cancer, can also have clinically meaningful anticancer effects. In the present article we review the available data indicating that bisphosphonates can reduce disease recurrence and can maintain bone health in women with breast cancer receiving adjuvant therapy.

\section{Bone metastases and the bone marrow microenvironment}

Bone is a common site for tumor metastasis, and some primary cancers appear to have an especially high propensity for metastasis to bone [5]. For example, the majority of patients with metastatic breast cancer or prostate cancer (approximately 75\%) and a substantial proportion of patients with metastatic lung cancer (30 to 40\%) will develop bone metastases [5]. The tendency of cancer cells to metastasize to bone is probably the end result of several factors including vascular pathways, the highly vascular nature of bone marrow (which increases the probability that cancer cells will be deposited in bone marrow capillaries), and molecular characteristics of the cancer cells that allow them to adapt to the bone marrow microenvironment $[3,4,6]$. In fact, breast cancer cells have been shown to adopt an osteoblast-like phenotype that may help them survive in the bone marrow [7]. Once in the bone marrow, CSCs may remain dormant for prolonged periods of time; however, the specific signals that control CSC dormancy and reactivation are currently not well understood [3].

Several distinct niches in the bone marrow allow CSCs to interact with osteoblasts (endosteal niche) and hematopoietic stem cells (vascular niche), and these niches can shelter CSCs from adjuvant therapies [4]. Contact with integrins and exposure to bone-derived cytokines in the bone marrow can reduce proapoptotic signaling, and cell-adhesion molecules bind to receptors on cancer cells and promote drug resistance [3]. Dormant CSCs in the bone marrow (often referred to as disseminated tumor cells) are thought to be the source for distant metastasis to secondary sites, and may be 
reactivated by osteoclast-mediated release of bonederived growth factors. Indeed, a strong correlation between disseminated tumor cells in bone marrow or circulating CSCs in the bloodstream and an increased risk of disease recurrence (distant and locoregional) has been demonstrated in several studies [8-10]. In addition, many chemotherapy and endocrine therapy regimens increase bone turnover and release of growth factors, supporting CSC growth in the bone. Chemotherapy could therefore both lead to the death of and facilitate the survival (through dormancy in the bone marrow) of cancer cells.

\section{Preventing bone metastases with bone-targeted therapies}

The goal of adjuvant therapy for early-stage breast cancer is to reduce the risk of disease recurrence by targeting residual CSCs in the blood, regional lymph nodes, bone marrow, and ipsilateral and contralateral breast tissue. For most patients with endocrine-responsive breast cancer, surgical resection followed by adjuvant endocrine therapy produces excellent outcomes, and the risk of relapse is low. This approach may fall short in some women, however, primarily because quiescent CSCs in the bone marrow are resistant to cytotoxic chemotherapy or other targeted adjuvant therapies that are effective only against actively cycling cancer cells. For example, adjuvant endocrine therapy effectively reduces the proliferation of breast cancer cells by reducing circulating estrogen to barely detectable levels, or by blocking the action of estrogen (that is, tamoxifen). Reducing estrogen levels also increases bone turnover, however, which may render the bone marrow environment more conducive to the survival of CSCs. As a result, adjuvant therapies that target the microenvironment in addition to the CSCs may indirectly affect the ability of dormant cells to survive and reactivate, and therefore could be more successful.

There is growing interest in using agents such as bisphosphonates to target CSCs in the bone microenvironment. Because bisphosphonates inhibit osteoclastmediated bone resorption, they reduce the release of bone-derived growth factors and other modulators necessary to promote cancer cell growth, differentiation, and tumor formation in bone. For example, the bisphosphonate zoledronic acid (ZOL) was shown in preclinical assays to prevent mesenchymal stem cells from secreting factors (RANTES and IL-6) involved in breast cancer migration and proliferation [11]. Adding ZOL also sensitizes colon CSCs to $\gamma \delta$ T-cell-mediated cytotoxicity [12]. In addition, data from multiple clinical trials suggest that bone-targeted therapy not only renders the bone a less hospitable environment, but may also directly affect the viability of CSCs. Recently, clinical trials in women with breast cancer suggested that bisphosphonates can improve outcomes by targeting both the seed (the CSCs) and the soil (the bone marrow microenvironment) [13-15]. Indeed, ZOL was shown to reduce disseminated tumor cells in four phase II trials in women with breast cancer (total $n=435$ ) [16-21]. In addition, investigational therapies - such as receptor activator of NF- $\mathrm{KB}$ ligand inhibitors, Src inhibitors, cathepsin $\mathrm{K}$ inhibitors, and integrin inhibitors - may render the bone microenvironment less favorable for cancer cell growth; however, their efficacy has not been established clinically. The unique potential of bisphosphonates to prevent bone metastases may be that they have both direct and indirect anticancer activity (targeting the cancer cells and bone).

\section{Bisphosphonate adjuvant clinical trials}

The potential anticancer activity of adjuvant bisphosphonate therapy for reducing disease recurrence has been examined in several clinical trials in women with early-stage breast cancer. Data from two clinical trials $(n=1,359)$ indicated that patients who received oral clodronate $(1,600 \mathrm{mg} /$ day for 2 years $)$ experienced a delay in developing bone metastases and showed improved disease-free survival and overall survival [22,23]. Conversely, another trial $(n=299)$ of oral clodronate $(1,600 \mathrm{mg} /$ day for 3 years) found no significant survival benefit; however, imbalances in the clodronate and control groups may have contributed to the lack of anticancer effect in this trial [24,25]. Although two out of the three trials showed a benefit with adjuvant clodronate, a meta-analysis of data from breast cancer trials was unable to detect a significant overall survival benefit or a significant reduction in bone metastases (Figure 1) [23,24,26,27]. Data from a trial in patients receiving adjuvant chemotherapy for breast cancer $(n=953)$ suggested that oral pamidronate $(150 \mathrm{mg}$ twice daily for 4 years) does not improve disease outcomes in patients in this setting [28]. Oral pamidronate may not, however, be as efficacious as the approved intravenous formulation.

Although trials of oral bisphosphonates (clodronate and pamidronate) have produced variable results, recent clinical trials of intravenous ZOL have demonstrated somewhat more consistent anticancer benefits in the adjuvant setting. In the ABCSG-12 trial $(n=1,803)$, premenopausal women with endocrine-responsive breast cancer received goserelin and were randomized to tamoxifen or anastrozole, with or without ZOL (4 mg every 6 months) [15]. After a median follow-up of 48 months, ZOL significantly reduced the risk of diseasefree survival events by $36 \%$ (hazard ratio $=0.64 ; P=0.01$ ) (Figure 2) [14,15,29], and produced a trend toward improved overall survival compared with patients who received endocrine therapy without ZOL. Overall, adding 


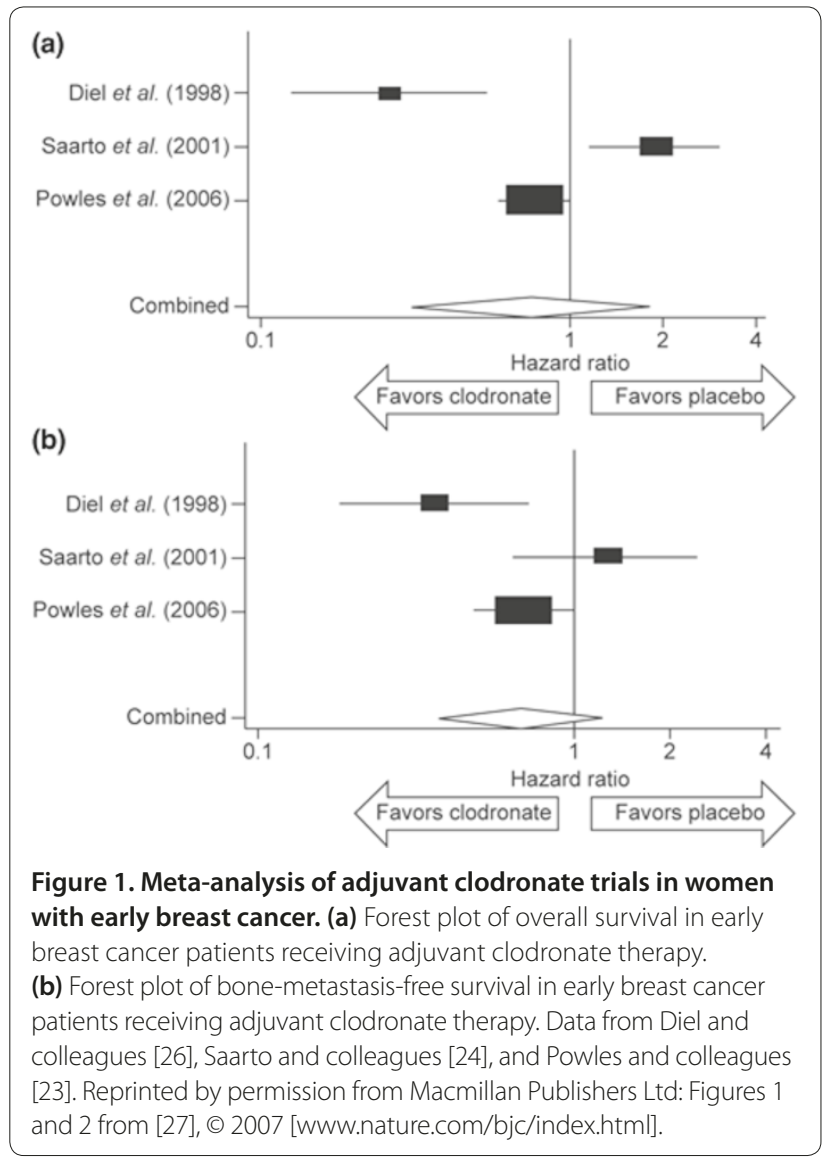

ZOL to endocrine therapy reduced the number of locoregional, contralateral, and distant recurrences (at bone and nonbone sites). At 62 months' median followup, more than 2 years after treatment ended, ZOL continued to reduce the risk of disease-free survival events by $32 \%$ (hazard ratio $=0.68 ; P=0.009$ ), with similar risk reductions in each of the endocrine therapy arms (Figure 2) $[14,15,29]$. Similar anticancer effects of ZOL were also observed in a trial in postmenopausal women with early breast cancer receiving adjuvant endocrine therapy. Among women enrolled in the ZO-FAST study $(n=1,065)$, patients who received upfront ZOL had fewer disease recurrence events at all sites, and ZOL reduced the relative risk of disease-free survival events by $41 \%$ (hazard ratio $=0.59 ; P=0.0314$ ) compared with patients in the delayed-ZOL group at 36 months (Figure 2) [14,15,29].

In addition to the anticancer effects observed in adjuvant breast cancer trials, an exploratory analysis of patients with stage II/III breast cancer who received neoadjuvant therapy with or without ZOL $(n=205)$ in the AZURE trial (total $n=3,360$ ) found that ZOL had anticancer effects on the primary tumor [13]. In this substudy, ZOL reduced residual invasive tumor size by
44\% (15.5 mm vs. $27.4 \mathrm{~mm}$ for chemotherapy alone; $P=0.006)$ and improved complete pathologic response nearly twofold in patients who received ZOL combined with neoadjuvant chemotherapy compared with neoadjuvant chemotherapy alone.

Additional data on the potential anticancer benefits of antiresorptive agents have emerged from the benign osteoporosis setting. In three recent large database studies (total $n=164,718$ ), healthy postmenopausal women receiving oral bisphosphonates to treat osteoporosis were found to have a significantly reduced risk of breast cancer compared with women who did not receive bisphosphonates, an effect that appeared to persist even after indirectly compensating for likely differences in bone mineral density between users and nonusers of bisphosphonates [30-32]. These data support the anticancer benefits of bisphosphonates observed in women receiving adjuvant breast cancer therapy, and suggest that the anticancer benefits of bisphosphonate therapy may be clinically meaningful even early in the disease course, before the cancer has reached a detectable level.

Taken together, these data are intriguing and suggest that bisphosphonates can have anticancer effects on the primary tumor and on disseminated CSCs. Several ongoing clinical trials of bisphosphonates in the neoadjuvant and adjuvant settings will further define the efficacy of these agents in the breast cancer setting.

\section{Maintaining bone health in women with early breast cancer}

It is well understood that many therapies for women with early-stage breast cancer can have negative effects on bone and may result in significant bone loss - that is, low bone mineral density (BMD) - within the first 1 to 2 years of therapy. In premenopausal women, cytotoxic chemotherapy can induce premature menopause and, in women with hormone-responsive breast cancer, ovarian suppression and endocrine therapy can cause rapid bone loss [33,34]. Similarly, adjuvant aromatase inhibitor therapy is associated with significant bone loss and increased fracture risk in postmenopausal women compared with women who received tamoxifen [35-38]. At diagnosis, women with breast cancer may already have several additional risk factors, unrelated to bone loss from breast cancer therapies, which add to their fracture risk. These baseline risk factors may include age ( $>65$ years), a history of fragility fracture after the age of 50 , body mass index $<20 \mathrm{~kg} / \mathrm{m}^{2}$, family history of osteoporosis, current or history of smoking, and oral corticosteroid use $>6$ months [1]. Each of these risk factors has been shown to increase a woman's fracture risk independent of BMD and is important in determining her overall fracture risk. The bone health of women with early breast cancer is often under assault by 


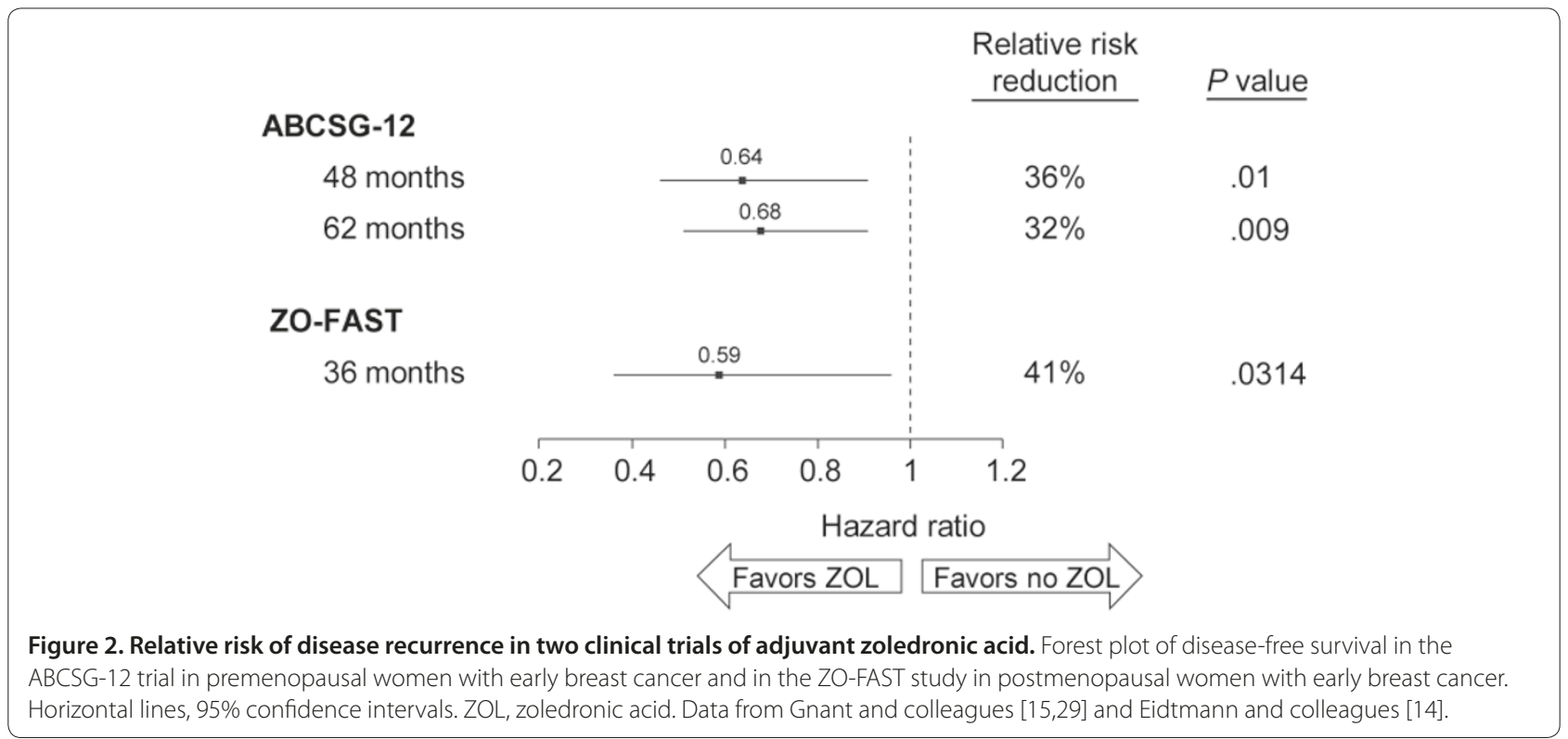

several factors; it is therefore of great importance to proactively address these risks through a combination of diet and lifestyle changes, as well as through pharmaceutical intervention when needed.

Several recent clinical trials examined the use of bisphosphonates to prevent bone loss associated with adjuvant endocrine therapy in premenopausal and postmenopausal women with early-stage breast cancer. Results from early trials of oral bisphosphonates demonstrated that these agents have only limited efficacy for preventing cancer treatment-induced bone loss and may be associated with poor patient compliance for treatment regimens outside the clinical trial setting. In the recent small-scale ARIBON study in patients $(n=50)$ with early breast cancer and osteopenia receiving anastrozole (1 mg/day), however, monthly oral ibandronate $(150 \mathrm{mg})$ improved lumbar spine BMD compared with baseline by approximately $3 \%$ after 1 and 2 years of therapy [39]. In two other studies in postmenopausal women receiving anastrozole $(1 \mathrm{mg} /$ day) for prevention ( $n=59)$ or for treatment $(n=118)$ of endocrineresponsive breast cancer, weekly oral risedronate improved lumbar spine and/or hip BMD compared with baseline [40,41]. Additionally, the SABRE trial showed that oral risedronate (35 $\mathrm{mg} /$ week) inhibited lumbar spine and total hip BMD loss for up to 24 months of treatment in postmenopausal women with a moderate to high risk of fragility fracture receiving anastrozole (1 mg/day) [42].

Intravenous bisphosphonates (for example, ZOL) can also prevent bone loss associated with adjuvant endocrine therapy in premenopausal and postmenopausal women. In the ABCSG-12 trial bone substudy $(n=404)$ in premenopausal women, adding ZOL maintained stable BMD during 3 years of endocrine therapy, and increased BMD for at least 2 years after treatment completion [43]. In four similarly designed trials (total $n=2,240$ ), upfront ZOL (4 mg every 6 months) significantly increased BMD in postmenopausal women during adjuvant letrozole therapy compared with baseline [14,44-46]. Across all studies, the overall percentage difference in BMD between the upfront-ZOL and delayed-ZOL groups continued to increase for up to 5 years [47]. Although these studies were not powered to detect between-group differences in fracture incidence, fewer fractures occurred in women who received upfront $\mathrm{ZOL}$.

Current oncology guidelines for addressing bone health in women receiving adjuvant endocrine therapy for early breast cancer rely mainly on BMD T scores to determine the fracture risk and to guide treatment. The American Society of Clinical Oncology guidelines published in 2003 rely on BMD as an indicator, and only recommend antiresorptive therapy with bisphosphonates in women who are osteoporotic [48]. Recently updated osteoporosis guidelines from the World Health Organization and the National Osteoporosis Foundation use BMD in addition to risk factors as indicators (family history of hip fracture; personal history of fracture, rheumatoid arthritis, or secondary osteoporosis; glucocorticoid use; smoking; alcohol intake) to decide when to initiate bisphosphonate therapy. Although the recently developed FRAX algorithm (used by the World Health Organization and the National Osteoporosis Foundation) can estimate fracture risk in healthy postmenopausal women, it is not appropriate for women with breast cancer because it does not adequately assess the fracture risk associated 


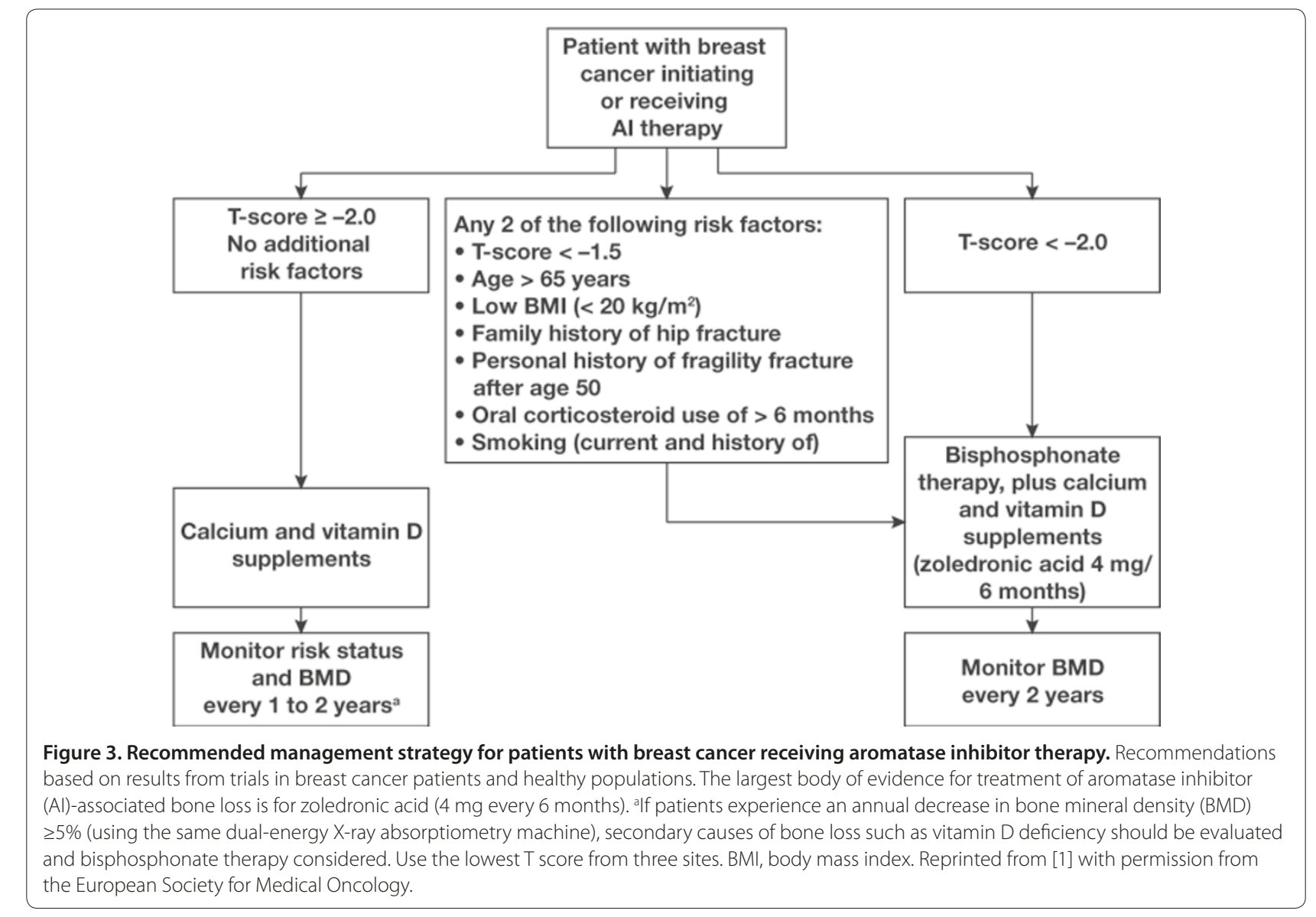

with breast cancer therapy. In addition, BMD assessment may not be routinely available for breast cancer patients.

As the importance of clinical risk factors for fracture has become increasingly apparent, emerging guidance from oncology experts has evolved to include an overall fracture risk assessment using clinical risk factors and BMD when available. For example, experts from the UK recommend using risk factors, age, and BMD to determine whom to treat [49]. Similarly, a group from Belgium recommends using specific risk factors for osteoporotic fractures (age, prior fragility fracture, medication use, or disease or medical condition that is associated with low bone mass or bone loss) to assess fracture risk [50]. Finally, an international panel of experts recommends using identified risk factors ( $\mathrm{T}$ score $<1.5$, age $>65$ years, body mass index $<20 \mathrm{~kg} / \mathrm{m}^{2}$, family history of hip fracture, personal history of fragility fracture after age 50, oral corticosteroid use $>6$ months, and smoking) with or without BMD (Figure 3) [1]. Although the details of the algorithms used to assess fracture risk in women with breast cancer vary slightly between expert groups, the overall consensus seems to favor a comprehensive fracture risk evaluation to determine who should receive antiresorptive therapy. Combining aromatase inhibitor therapy with bisphosphonate treatment in women with a high risk of fracture also appears to perhaps allow patients to gain the anticancer benefit of aromatase inhibitor therapy without the negative effects on bone health.

\section{Conclusions}

The available evidence clearly indicates that bone health is an important consideration when initiating therapy for women with early breast cancer. Recent clinical guidelines have improved identification of patients who would benefit from adjuvant bisphosphonate therapy in this setting. In addition to observed beneficial effects on $\mathrm{BMD}$, recent data suggest there is also a potential for disease recurrence advantages with bisphosphonates. Based on the anticancer activity of bisphosphonates for reducing disease recurrence in the adjuvant breast cancer setting, as well as the provocative finding of reduced breast cancer incidence in the osteoporosis trials, there is increasing evidence that beginning bisphosphonate therapy early in the disease course may provide the greatest benefits. 
This article is part of a review series on Bisphosphonates and other bone-targeted agents in breast cancer, edited by Janine Mansi and Robert Coleman. Other articles in the series can be found online at http://breast-cancer-research.com/series/bisphosphonates

\section{Abbreviations}

BMD, bone mineral density; CSC, cancer stem cell; IL, interleukin; NF, nuclear factor; RANTES, regulated on activation, normal T-cell expressed and secreted; ZOL, zoledronic acid.

\section{Competing interests}

MG reports receiving research support from and serving as a consultant for AstraZeneca, Novartis, and Pfizer, and receiving lecture fees and honoraria for participation on advisory boards from AstraZeneca, Novartis, Sanofi-Aventis, Roche, Schering, Amgen, and Pfizer. PH has received honoraria, unrestricted educational grants, and research funding from the following companies: Amgen, AstraZeneca, Eli Lilly, GlaxoSmithKline, Novartis, Pfizer, Roche, SanofiAventis, and Wyeth.

\section{Acknowledgements}

Financial support for medical editorial assistance was provided by Novartis Pharmaceuticals. The authors thank Michael Hobert, PhD, ProEd Communications, Inc., for medical editorial assistance with this manuscript.

\section{Author details}

'Department of Surgery, Medical University of Vienna, A-1090 Währinger Gürtel 18-20, Vienna, Austria. ${ }^{2}$ Department of Endocrinology and Reproductive Medicine, Philipps University of Marburg, Universitäts Klinikum Giessen und Marburg, Standort Marburg Balderingstrasse, 35034 Marburg, Germany.

Published: 17 December 2010

\section{References}

1. Hadji P, Body J-J, Aapro MS, Brufsky A, Coleman RE, Guise T, Lipton A, TubianaHulin M: Practical guidance for the management of aromatase inhibitorassociated bone loss. Ann Oncol 2008, 19:1407-1416.

2. Aguirre-Ghiso JA: The problem of cancer dormancy: understanding the basic mechanisms and identifying therapeutic opportunities. Cell Cycle 2006, 5:1740-1743.

3. Meads MB, Hazlehurst LA, Dalton WS: The bone marrow microenvironment as a tumor sanctuary and contributor to drug resistance. Clin Cancer Res 2008, 14:2519-2526.

4. Shiozawa Y, Havens AM, Pienta KJ, Taichman RS: The bone marrow niche: habitat to hematopoietic and mesenchymal stem cells, and unwitting host to molecular parasites. Leukemia 2008, 22:941-950.

5. Coleman RE: Skeletal complications of malignancy. Cancer 1997, 80(8 Suppl):1588-1594.

6. Chambers AF, Groom AC, MacDonald IC: Dissemination and growth of cancer cells in metastatic sites. Nat Rev Cancer 2002, 2:563-572.

7. Bellahcene A, Bachelier R, Detry C, Lidereau R, Clezardin P, Castronovo V: Transcriptome analysis reveals an osteoblast-like phenotype for human osteotropic breast cancer cells. Breast Cancer Res Treat 2007, 101:135-148.

8. Bidard FC, Vincent-Salomon A, Gomme S, Nos C, de Rycke Y, Thiery JP, SigalZafrani B, Mignot L, Sastre-Garau X, Pierga JY: Disseminated tumor cells of breast cancer patients: a strong prognostic factor for distant and local relapse. Clin Cancer Res 2008, 14:3306-3311.

9. Braun S, Vogl FD, Naume B, Janni W, Osborne MP, Coombes RC, Schlimok G, Diel IJ, Gerber B, Gebauer G, Pierga JY, Marth C, Oruzio D, Wiedswang G, Solomayer EF, Kundt G, Strobl B, Fehm T, Wong GY, Bliss J, Vincent-Salomon A, Pantel K: A pooled analysis of bone marrow micrometastasis in breast cancer. N Engl J Med 2005, 353:793-802.

10. Cristofanilli M, Hayes DF, Budd GT, Ellis MJ, Stopeck A, Reuben JM, Doyle GV, Matera J, Allard WJ, Miller MC, Fritsche HA, Hortobagyi GN, Terstappen LW: Circulating tumor cells: a novel prognostic factor for newly diagnosed metastatic breast cancer. J Clin Oncol 2005, 23:1420-1430.

11. Normanno N, Gallo M, Lamura L, De Luca A: Effect of zoledronic acid acts on the interaction between mesenchymal stem cells and breast cancer cells within the bone microenvironment [abstract 10602]. J Clin Oncol 2010, 28(15 Suppl):748s.
12. Todaro M, D'Asaro M, Caccamo N, lovino F, Francipane MG, Meraviglia S, Orlando V, La Mendola C, Gulotta G, Salerno A, Dieli F, Stassi G: Efficient killing of human colon cancer stem cells by gammadelta T lymphocytes. $\mathrm{J} / \mathrm{mm}$ unol 2009, 182:7287-7296.

13. Coleman RE, Winter MC, Cameron D, Bell R, Dodwell D, Keane MM, Gil M, Ritchie D, Passos-Coelho JL, Wheatley D, Burkinshaw R, Marshall SJ, Thorpe H; AZURE (BIG01/04) Investigators: The effects of adding zoledronic acid to neoadjuvant chemotherapy on tumour response: exploratory evidence for direct anti-tumour activity in breast cancer. Br J Cancer 2010, 102:1099-1105.

14. Eidtmann H, de Boer R, Bundred N, Llombart-Cussac A, Davidson N, Neven P, von Minckwitz G, Miller J, Schenk N, Coleman R: Efficacy of zoledronic acid in postmenopausal women with early breast cancer receiving adjuvant letrozole: 36-month results of the ZO-FAST study. Ann Oncol 2010, 21:2188-2194.

15. Gnant M, Mlineritsch B, Schippinger W, Luschin-Ebengreuth G, Pöstlberger S, Menzel C, Jakesz R, Seifert M, Hubalek M, Bjelic-Radisic V, Samonigg H, Tausch C, Eidtmann H, Steger G, Kwasny W, Dubsky P, Fridrik M, Fitzal F, Stierer M, Rücklinger E, Greil R; ABCSG-12 Trial Investigators, Marth C: Endocrine therapy plus zoledronic acid in premenopausal breast cancer. N Eng/ J Med 2009, 360:679-691.

16. Aft $R$, Naughton $M$, Trinkaus $K$, Watson $M$, Ylagan $L$, Chavez-MacGregor $M$, Zhai J, Kuo S, Shannon W, Diemer K, Herrmann V, Dietz J, Ali A, Ellis M, Weiss P, Eberlein T, Ma C, Fracasso PM, Zoberi I, Taylor M, Gillanders W, Pluard T, Mortimer J, Weilbaecher K: Effect of zoledronic acid on disseminated tumour cells in women with locally advanced breast cancer: an open label, randomised, phase 2 trial. Lancet Oncol 2010, 11:421-428.

17. Lin AY, Park JW, Scott J, Melisko M, Goga A, Moasser MM, Moore DH, Rugo HS Zoledronic acid as adjuvant therapy for women with early stage breast cancer and disseminated tumor cells in bone marrow [abstract 559]. J Clin Oncol 2008, 26(15 Suppl):20S.

18. Rack B, Schindllbeck C, Strobl B, Sommer H, Friese K, Janni W: Efficacy of zoledronate in treating persisting isolated tumor cells in bone marrow in patients with breast cancer. A phase II pilot study. Dtsch Med Wochenschr 2008, 133:285-289.

19. Rack BK, Jueckstock J, Genss E-M, Schoberth A, Schindlbeck C, Strobl B, Heinrigs M, Rammel G, Zwingers T, Sommer H, Friese K, Janni W: Effect of zoledronate on persisting isolated tumor cells in the bone marrow of patients without recurrence of early breast cancer [abstract 511]. Breast Cancer Res Treat 2007, 106(Suppl 1):S40.

20. Solomayer E, Gebauer G, Hirnle P, Janni W, Lück HJ, Becker S, Huober J, Kraemer B, Wackwitz B, Fehm T: Influence of zoledronic acid on disseminated tumor cells (DTC) in primary breast cancer patients [abstract 2048]. Cancer Res 2008, 69(2 Suppl):170s-171s.

21. Greenberg S, Park JW, Melisko ME, Goga A, Moasser MM, Anderson M, Scott $J$, Petrillo LA, Moore DH, Rugo HS: Effect of adjuvant zoledronic acid (ZOL) on disseminated tumor cells (DTC) in the bone marrow (BM) of women with early-stage breast cancer (ESBC): updated results [abstract 1002]. $J$ Clin Oncol 2010, 28(15 Suppl):114s.

22. Diel IJ, Jaschke A, Solomayer EF, Gollan C, Bastert G, Sohn C, Schuetz F: Adjuvant oral clodronate improves the overall survival of primary breast cancer patients with micrometastases to the bone marrow: a long-term follow-up. Ann Oncol 2008, 19:2007-2011.

23. Powles T, Paterson A, McCloskey E, Schein P, Scheffler B, Tidy A, Ashley S, Smith I, Ottestad L, Kanis J: Reduction in bone relapse and improved survival with oral clodronate for adjuvant treatment of operable breast cancer [ISRCTN83688026]. Breast Cancer Res 2006, 8:R13.

24. Saarto T, Blomqvist C, Virkkunen P, Elomaa I: Adjuvant clodronate treatment does not reduce the frequency of skeletal metastases in node-positive breast cancer patients: 5 -year results of a randomized controlled trial. J Clin Oncol 2001, 19:10-17.

25. Saarto T, Vehmanen L, Virkkunen P, Blomqvist C: Ten-year follow-up of a randomized controlled trial of adjuvant clodronate treatment in nodepositive breast cancer patients. Acta Oncol 2004, 43:650-656.

26. Diel IJ, Solomayer EF, Costa SD, Gollan C, Goerner R, Wallwiener D, Kaufmann $\mathrm{M}$, Bastert G: Reduction in new metastases in breast cancer with adjuvant clodronate treatment. N Engl J Med 1998, 339:357-363.

27. Ha TC, Li H: Meta-analysis of clodronate and breast cancer survival. Br J Cancer 2007, 96:1796-1801.

28. Kristensen B, Ejlertsen B, Mouridsen HT, Jensen MB, Andersen J, Bjerregaard B, Cold S, Edlund P, Ewertz M, Kamby C, Lindman H, Nordenskjöld B, Bergh J: 
Bisphosphonate treatment in primary breast cancer: results from a randomised comparison of oral pamidronate versus no pamidronate in patients with primary breast cancer. Acta Oncol 2008, 47:740-746.

29. Gnant M, Mlineritsch B, Stoeger G, Luschin-Ebengreuth G, Poestlberger S, Dubsky PC, Jakesz R, Singer CF, Eidtmann H, Greil R: Mature results from ABCSG-12: adjuvant ovarian suppression combined with tamoxifen or anastrozole, alone or in combination with zoledronic acid, in premenopausal women with endocrine-responsive early breast cancer [abstract 533]. J Clin Oncol 2010, 28(15 Suppl):75s.

30. Chlebowski RT, Chen Z, Cauley JA, Anderson G, Rodabough RJ, McTiernan A, Lane DS, Manson JE, Snetselaar L, Yasmeen S: Oral bisphosphonate use and breast cancer incidence in postmenopausal women. $J$ Clin Oncol 2010, 28:3582-3590.

31. Rennert G, Pinchev M, Rennert HS: Use of bisphosphonates and risk of postmenopausal breast cancer. J Clin Oncol 2010, 28:3577-3581.

32. Newcomb PA, Trentham-Dietz A, Hampton JM: Bisphosphonates for osteoporosis treatment are associated with reduced breast cancer risk. Br J Cancer 2010, 102:799-802.

33. Fogelman I, Blake GM, Blamey R, Palmer M, Sauerbrei W, Schumacher M, Serin D, Stewart A, Wilpshaar W: Bone mineral density in premenopausal women treated for node-positive early breast cancer with 2 years of goserelin or 6 months of cyclophosphamide, methotrexate and 5-fluorouracil (CMF). Osteoporos Int 2003, 14:1001-1006.

34. Shapiro CL, Manola J, Leboff M: Ovarian failure after adjuvant chemotherapy is associated with rapid bone loss in women with earlystage breast cancer. J Clin Oncol 2001, 19:3306-3311.

35. Eastell R, Adams JE, Coleman RE, Howell A, Hannon RA, Cuzick J, Mackey JR, Beckmann MW, Clack G: Effect of anastrozole on bone mineral density: 5 -year results from the anastrozole, tamoxifen, alone or in combination trial 18233230. J Clin Oncol 2008, 26:1051-1057.

36. Perez EA, Josse RG, Pritchard KI, Ingle JN, Martino S, Findlay BP, Shenkier TN, Tozer RG, Palmer MJ, Shepherd LE, Liu S, Tu D, Goss PE: Effect of letrozole versus placebo on bone mineral density in women with primary breast cancer completing 5 or more years of adjuvant tamoxifen: a companion study to NCIC CTG MA.17. J Clin Oncol 2006, 24:3629-3635.

37. Howell A, Cuzick J, Baum M, Buzdar A, Dowsett M, Forbes JF, Hoctin-Boes G, Houghton J, Locker GY, Tobias JS: Results of the ATAC (Arimidex, Tamoxifen, Alone or in Combination) trial after completion of 5 years' adjuvant treatment for breast cancer. Lancet 2005, 365:60-62.

38. Thurlimann B, Keshaviah A, Coates AS, Mouridsen H, Mauriac L, Forbes JF, Paridaens R, Castiglione-Gertsch M, Gelber RD, Rabaglio M: A comparison of letrozole and tamoxifen in postmenopausal women with early breast cancer. N Engl J Med 2005, 353:2747-2757.

39. Lester JE, Dodwell D, Purohit OP, Gutcher SA, Ellis SP, Thorpe R, Horsman JM, Brown JE, Hannon RA, Coleman RE: Prevention of anastrozole-induced bone loss with monthly oral ibandronate during adjuvant aromatase inhibitor therapy for breast cancer. Clin Cancer Res 2008, 14:6336-6342.

40. Confavreux CB, Fontana A, Guastalla JP, Munoz F, Brun J, Delmas PD: Estrogen-dependent increase in bone turnover and bone loss in postmenopausal women with breast cancer treated with anastrozole. Prevention with bisphosphonates. Bone 2007, 41:346-352.

41. Singh S, Cuzick J, Edwards R, Blake G, Truscott J, Coleman R, Eastell R, Howell $A$ : Effect of anastrozole on bone mineral density after one year of treatment: results from bone sub-study of the International Breast Cancer Intervention Study (IBIS-II) [abstract 28]. Breast Cancer Res Treat 2007, 106(Suppl 1):S9.
42. Van Poznak C, Hannon RA, Mackey JR, Campone M, Apffelstaedt JP, Clack G, Barlow D, Makris A, Eastell R: Prevention of aromatase inhibitor-induced bone loss using risedronate: the SABRE trial. J Clin Oncol 2010, 28:967-975.

43. Gnant M, Mlineritsch B, Luschin-Ebengreuth $G$, Kainberger F, Kässmann $H$, Piswanger-Sölkner JC, Seifert M, Ploner F, Menzel C, Dubsky P, Fitzal F, BjelicRadisic V, Steger G, Greil R, Marth C, Kubista E, Samonigg H, Wohlmuth P, Mittlböck M, Jakesz R; Austrian Breast and Colorectal Cancer Study Group (ABCSG): Adjuvant endocrine therapy plus zoledronic acid in premenopausal women with early-stage breast cancer: 5-year follow-up of the ABCSG-12 bone-mineral density substudy. Lancet Oncol 2008, 9:840-849.

44. Brufsky AM, Bosserman LD, Caradonna RR, Haley BB, Jones CM, Moore HCF, Jin L, Warsi GM, Ericson SG, Perez EA: Zoledronic acid effectively prevents aromatase inhibitor-associated bone loss in postmenopausal women with early breast cancer receiving adjuvant letrozole: Z-FAST study 36-month follow-up results. Clin Breast Cancer 2009, 9:77-85.

45. Llombart A, Frassoladti A, Paija O, Sleeboom HP, Jerusalem G, Mebis J, Deleu I, Miller J, Schenk N, Neven P: Effect of zoledronic acid on aromatase inhibitor-associated bone loss in postmenopausal women with early breast cancer receiving adjuvant letrozole: E-ZO-FAST 36-month follow-up [abstract 213]. In Proceedings of the American Society of Clinical Oncology 2009 Breast Cancer Symposium; 8-10 October 2009; San Francisco. [http://www. asco.org/ASCOv2/Meetings/Abstracts?\&vmview=abst_detail_view\&conflD= 70\&abstract|D=40178]

46. Hines SL, Sloan JA, Atherton PJ, Perez EA, Dakhil SR, Johnson DB, Reddy PS, Dalton RJ, Mattar BI, Loprinzi CL: Zoledronic acid for treatment of osteopenia and osteoporosis in women with primary breast cancer undergoing adjuvant aromatase inhibitor therapy. Breast 2010, 19:92-96.

47. Brufsky A, Harker WG, Beck JT, Carroll R, Jin L, Warsi G, Argonza-Aviles E, Ericson SG, Perez EA: The effect of zoledronic acid on aromatase inhibitorassociated bone loss in postmenopausal women with early breast cancer receiving adjuvant letrozole: the Z-FAST study 5-year final follow-up [abstract 4083]. Cancer Res 2009, 69(24 Suppl):733s-734s.

48. Hillner BE, Ingle JN, Chlebowski RT, Gralow J, Yee GC, Janjan NA, Cauley JA, Blumenstein BA, Albain KS, Lipton A, Brown S; American Society of Clinical Oncology: American Society of Clinical Oncology 2003 update on the role of bisphosphonates and bone health issues in women with breast cancer. J Clin Oncol 2003, 21:4042-4057.

49. Reid DM, Doughty J, Eastell R, Heys SD, Howell A, McCloskey EV, Powles T, Selby P, Coleman RE: Guidance for the management of breast cancer treatment-induced bone loss: a consensus position statement from a UK Expert Group. Cancer Treat Rev 2008, 34(Suppl 1):S3-S18.

50. Body JJ, Bergmann P, Boonen S, Boutsen Y, Devogelaer JP, Goemaere S, Reginster JY, Rozenberg S, Kaufman JM: Management of cancer treatmentinduced bone loss in early breast and prostate cancer - a consensus paper of the Belgian Bone Club. Osteoporos Int 2007, 18:1439-1450.

\section{doi:10.1186/bcr2768}

Cite this article as: Gnant M, Hadji P: Prevention of bone metastases and management of bone health in early breast cancer. Breast Cancer Research 2010, 12:216 